\title{
Spectrophotometric Determination of Certain Antiepileptic's in Tablets Using Vanillin Reagent
}

\author{
Taghreed A. Mohammed ${ }^{a \star}$ Mona A. Mohamed $^{b}$ \\ ${ }^{a}$ Department of Analytical Chemistry, National Organization for Drug Control and Research (NODCAR),6-Abu \\ Hazem street, Pyramids Ave. P.O.Box 29, Giza, Egypt. \\ E-mail address: dr.taghreednodcar@gmail.com \\ ${ }^{\mathrm{b}}$ Department of Elemental Analysis, National Organization for Drug Control and Research (NODCAR),6-Abu \\ Hazem street, Pyramids Ave. P.O.Box 29, Giza, Egypt. \\ E-mail address: nodcar1977@yahoo.com \\ *Corresponding author:dr.taghreednodcar@gmail.com
}

\begin{abstract}
A selective and new spectrophotometric method is described for detemination of three antiepileptic drugs; namely lamotrigine (LAM), gabapentin (GAB), and oxcarbazepine (OXC) in drug substances and in drug products using vanillin reagent as the chromogenic agent.The method is based on a coupling reaction between the cited drugs and vanillin reagent in acidic condition. Under optimized conditions, the yellow colored products were measured at 405, 396, and $400 \mathrm{~nm}$ respectively. Beer's law was obeyed at $(0.4-10),(0.1-10)$, and $(0.5-11) \mu \mathrm{g} / \mathrm{mL}$, and the calculated molar absorptivity values are $2.52 \times 10^{4}, 1.74 \times 10^{4}$, and $2.54 \times 10^{4} \mathrm{~L} / \mathrm{mol} / \mathrm{cm}$ for $\mathrm{LAM}, \mathrm{GAB}$, and OXC respectively. Sandell sensitivity, the limit of detection (LOD) and limit of quantification (LOQ) were calculated. No interference was observed from common additives found in drug products. The presented method was validated according to $\mathrm{ICH}$ guidelines. Statistical comparison of the results was performed using Student's $t$-test and $F$-ratio at $95 \%$ confidence level, and there was no significant difference between the reference and proposed method with regard to accuracy and precision. The method offers the advantages of rapidity, simplicity and sensitivity and low cost and can be easily applied to resource poor settings without the need for expensive instrumentation and reagents.
\end{abstract}

Keywords: Antiepileptic drugs; Chromogenic agent; ICH guidelines; Statistical comparison; Spectrophotometric method; Vanillin reagent.

\section{Council for Innovative Research}

Peer Review Research Publishing System

Journal: Journal of Advances in Chemistry

Vol. 11, No. 2

editorjaconline@gmail.com

www.cirjac.com 


\section{INTRODUCTION:}

Lamotrigine (LAM), 3, 5-diamino-6-(2, 3-dichlorophenyl)-1, 2, 4-triazine Figure 1 is an anticonvulsant drug. As an antiepileptic, it has been us ed successfully to treat epilepsy and bipolar disorder as immunotherapy and as an adjunct with other antiepileptic for treatment of partial and generalized toxic-chronic seizures. It is also used to treat neurological lesions and as a tranquilizer [1, 2]. LAM is the subject of monographs in the United States Phamacopeia[3] where by potentiometric method is recommended for its detemination. Several analytical methods have been reported for the determination of LAM in pharmaceuticals or in biological fluids including reverse-phase HPLC [4-6], GC with nitrogen phosphorous detector[7], capillary electrophores is [8], adsorptive stripping voltammetry[9,10] and spectrophotometry[1117]. The objective of the present work is to develop simple, rapid and precise UV spectroscopic method for the detemination of lamotrigine in drug substance and in drug products.

The new anti-convulsion drug Gabapentin (1-(amino methyl) cyclohexane acetic acid) Figure 1 is a structural analogue of amino butyric acid (GABA) and its action is attributed to the irreversible inhibition of the enzyme GABAtransaminase, thus preventing the physiological degradation of GABA in the brain. [18] Currently, GAB and its phamaceutical dosage forms are official in the United States Pharmacopeia and also different analytical methods are reported for its determination. These include high performance liquid chromatography [3], liquid chromatography-mass spectrometry [19], gas chromatography mass spectrometry [20], capillary electrophoresis [21], potentiometric [22], spectrofluorimetric [23], and colorimetric. [24-27]. Literature survey does not reveal any simple extractive spectroscopic method for determination of GBP. The present manuscript describes simple and sensitive spectroscopic procedures for the detemination of GAB in drug products.

Oxcarbazepine (10, 11-dihydro-10-oxo-5H-dibenzo [b, f] aze-pine-5-carboxamide), Figure 1.An antiepileptic drug, official in the United States Pharmacopeia [3] is a 10-keto analogue of carbamazepine with a similar therapeutic profile, but with less adverse effects and less clinical relevant phamacokinetic drug interactions [28]. OXC is indicated as first line drug in immunotherapy or polytherapy for the treatment of partial seizures with or without secondarily generalized tonic colonic epileptic seizures [29-30]. These actions are thought to be important in the prevention of synaptic neurotransmission and seizure spread in the intact brain [31]. In addition,increased potassium conductance and modulation of high voltage activated calcium channels may contribute to the anticonvulsant effects of the drug [32]. There is LC, GC, voltammetry, HPLCand several other methods for the quantification of oxcarbazepine and its main metabolites 10-hydroxy-10, 11- dihydrocarbamazepine and 10,11- dihydroxy-trans-10,11-dihydrocarbamazepine in biological fluids, which are reported [33-40], another method spectrophotometry[41-42] and voltammetry[43]. To our knowledge most of the reported methods mainly describe the determination of OXC in biological fluids but only a few methods are describing its detemination in phamaceutical formulations. In addition some of those methods are requiring expensive equipment, reagents and are also time consuming; an attempt is made here to develop a simple, rapid, economical and sensitive spectrophotometric method based on the reaction of OXC with vanillin in acidic medium for its determination either in pure or in dosage form.

Vanillin (4-hydroxy-3- methoxybenzaldehyde) Figure 1 is an organic compound containing an aldehyde, ether and phenolic moiety. It has been used as a chemical intermediate in the production of phamaceuticals and other chemicals. It is also used as a general purpose stain for TLC plate development to aid visualization. Use of it has also been reported in the quantitative determination of certain drugs by spectrophotometric reaction [44-49].

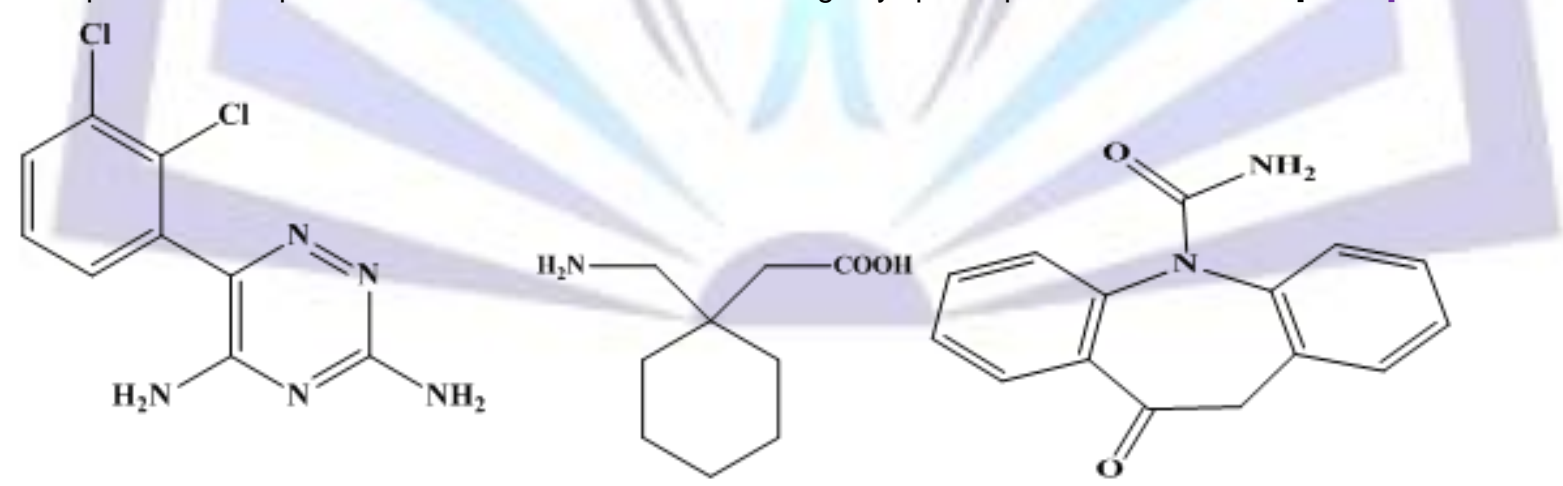

(a)

(b)

(c ) 
<smiles>COc1cc(C=O)ccc1O</smiles>

(d)

Figure 1 :Chemical structures of the investigated antiepileptic drugs (a) lamotrigine, (b) gabapentin, (c) oxcarbazepine and (d) vanillin reagent.

\section{EXPERIMENTAL PROCEDURES:}

\subsection{Instrument}

SHIMADZU UV-2450 PC Series Spectrophotometer (Tokyo - Japan) with two matched $1 \mathrm{~cm}$ quartz cells using the following spectral parameters: Scan mode: absorbance, Speed: fast and Slit width: $2 \mathrm{~nm}$

\subsection{Materials and Chemicals}

Lamotrigine (Batch no: 14LM000002) was kindly supplied by Delta Pharm and assayed for purity according to the official HPLC assay [3] to contain 99.95\% $\pm 0.12 \%$. Larogen $100 \mathrm{mg} / \mathrm{tab}$. (B.N. 13691), manufactured by Delta Pharm. Gabapentin (Batch no: 20121004) was kindly supplied by Mash Pharm. industry and assayed for purity according to the official HPLC assay [3] to contain $98.85 \% \pm 0.23 \%$. Gaptin $100 \mathrm{mg} / \mathrm{tab}$. (B.N. GA102) manufactured by Delta Pham. Oxcarbazepine (Batch no: OX0010514) was kindly supplied by Mash Pham phamaceutical industry and assayed for purity according to the official HPLC assay [3] to contain $99.87 \% \pm 0.28 \%$. Trileptal $150 \mathrm{mg} / \mathrm{tab}$. (B.N. 10000), manufactured by Novartis Com.

All chemicals are analytical grad, Methanol (LAB-SCAN), Hydrochloric acid 37\% (Honeywell), and Vanillin (Qualikems Fine Chemicals Pvt. Lid), Prepared by dissolving $5 \mathrm{gm}$. of vanillin in $100.0 \mathrm{~mL}$ of $1.0 \mathrm{M}$ methanolic hydrochloric acid.

\subsection{Standard Stock Solution of Drugs}

Accurately about $20 \mathrm{mg}$ of the drug substances (LAM, GAB, OXC) was weighed and dissolved in $1.0 \mathrm{M}$ methanolic hydrochloric acid and the volume is made up to the volume $100 \mathrm{ml}$ to give standard stock solution $(200 \mu \mathrm{g} / \mathrm{ml})$ and from this solution $10 \mathrm{ml}$ of sample was transferred in to separated $100 \mathrm{ml}$ volumetric flask and volume was made up to the mark $100 \mathrm{ml}$ with $1.0 \mathrm{M}$ methanolic hydrochloric acid to get concentration $(20 \mu \mathrm{g} / \mathrm{ml})$ as a working stander solution.

\subsection{Procedure for Calibration Curves}

An aliquot of $1.0 \mathrm{~mL}$ of the working stander solutions was transferred into a $10-\mathrm{mL}$ calibrated flask, $2.0 \mathrm{~mL}$ of $5 \%$ vanillin reagent was added, mixed well, the reaction was allowed to stand for about15 minutes, then the resulting colored products were measured at 405, 396, and $400 \mathrm{~nm}$ for LAM, GAB, and OXC respectively against blanks which treated similarly.

\subsection{Procedure for the Assay of Drug Products}

Twenty tablets were weighted accurately, the contents were mixed thoroughly. An accurate weight of the mixed powder equivalent to one tablet of $\mathrm{LAM}, \mathrm{GAB}$, and OXC were transferred into three separated 100 -ml conical flasks, 50-ml $1 \mathrm{M}$ methanolic hydrochloric acid was added, The contents were swirled and sonicated for $10 \mathrm{~min}$, then filtered through a What- mann No. 42 filter paper previously moisten with methanol. The collected filtrate was transferred quantitatively into $100-\mathrm{mL}$ calibrated flask; the resultant solutions were completed to mark with $1.0 \mathrm{M}$ methanolic hydrochloric acid and then subjected to subsequent dilution.

\section{RESULTS AND DISCUSSION}

\subsection{Absorption Spectra}

$\mathrm{LAM}, \mathrm{GAB}$, and $\mathrm{OXC}$ readily reacts with vanillin in methanolic hydrochloric acid solution yielding an intense yellow colored hydrazone as shown in the equation having an absorption maximum at 405,396, and400 $\mathrm{nm}$ (Schema 1). The reagent blank does not absorb around this wavelength. The hydrazone formed was stable in the temperature range 
$20-40^{\circ} \mathrm{C}$. The color of the products formed was stable for about 2 hours at room temperature $\left(30^{\circ} \mathrm{C}\right)$ followed by a steady decrease in absorbance values as shown in Figure 2.<smiles>COc1cc(C=[N+][C@H](C)[C@@H](C)C=O)ccc1O</smiles>

Investigated Drugs

Vanillin

Yellow Hydrazone

Scheme 1: Probable reaction scheme.

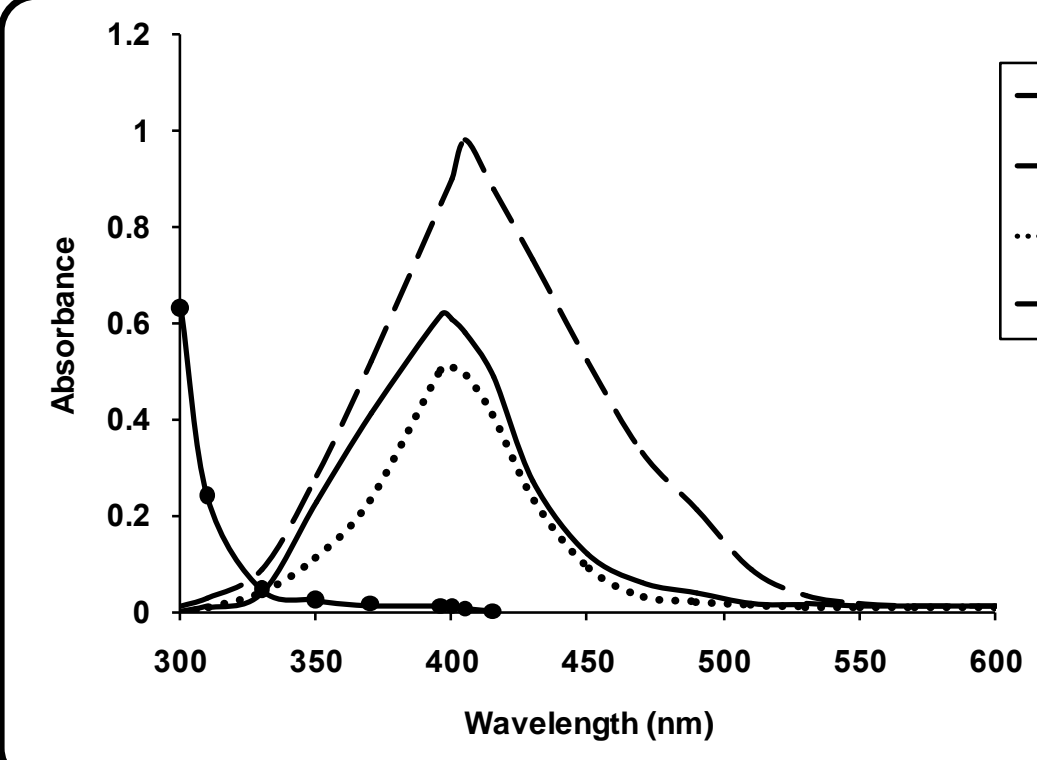

Figure 2 :Absorption spectra of LAM $\left(10 \mu \mathrm{gml}^{-1}\right)$, GAB $\left(6 \mu \mathrm{gml}^{-1}\right)$, and OXC $\left(5 \mu \mathrm{gml}^{-1}\right)$ - Vanillin $(5 \% \mathrm{w} / \mathrm{v})$ reaction product.

\subsection{Optimization of Experimental Variables}

Various experimental variables were optimized to achieve maximum sensitivity.

\subsubsection{Determination of effective reagent concentration}

Preliminary experiments were done in order to ascertain the effect of concentration and the volume of vanillin at the wavelength of maximum absomtion, 405,396, and $400 \mathrm{~nm}$. To series of LAM, GAB, and OXC solutions, varying concentrations (1-7\%) were added and the analytical procedure followed. After 15 minutes, the absorbance of each solution of three drugs was read at 405,396, and 400nm. It was observed that the analytical signal increased with an increase in reagent concentration up to $6 \%$. The concentration of vanillin therefore utilized was $5 \%$. Similarly, by fixing the vanillin concentration as $5 \%$ in series of $L A M, G A B$, and OXC solutions, different volumes of vanillin in the range of 0.5 - $4 \mathrm{ml}$ were added. The analytical procedure was then followed, after 15 minutes, the absorbance was read. It was observed that $2-\mathrm{ml}$ of $5 \%$ vanillin solution was optimal for the formation of color with maximum intensity. Therefore, 2 -ml of $5 \%$ vanillin solution was utilized for all measurements as shown inFigure 3 . 


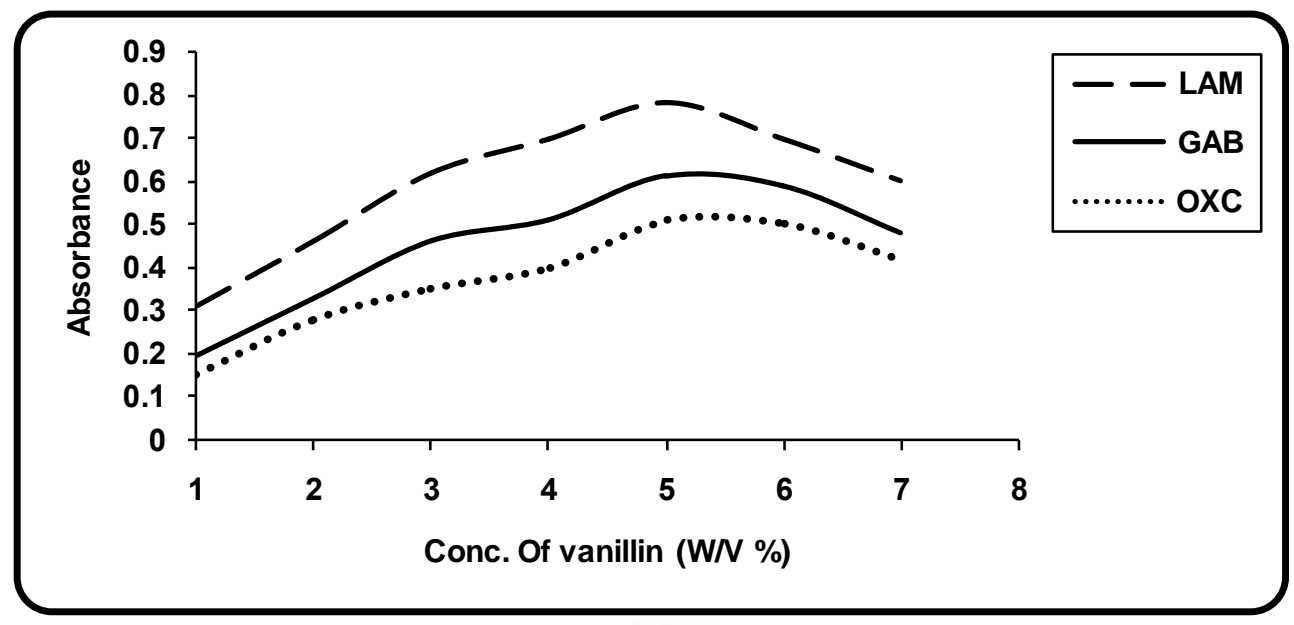

Figure 3 :Effect of conc. of (2-ml) of Vanillin in absorbance of LAM $\left(10 \mu \mathrm{gml}^{-1}\right)$, GAB $\left(6 \mu \mathrm{gml}^{-1}\right)$, and OXC $\left(5 \mu \mathrm{gml}^{-1}\right)-$ Vanillin $(5 \% \mathrm{w} / \mathrm{v})$ reaction products.

\subsubsection{Types of acids}

Reaction between vanillin reagent and antiepileptic drugs was found to proceed in acidic medium. So, different acids were tested. $1.0 \mathrm{M}$ methanolic Hydrochloric acid resulted in an increase of the absorbance intensity accompanied by hyper chromic shift as shown inFigure 4.

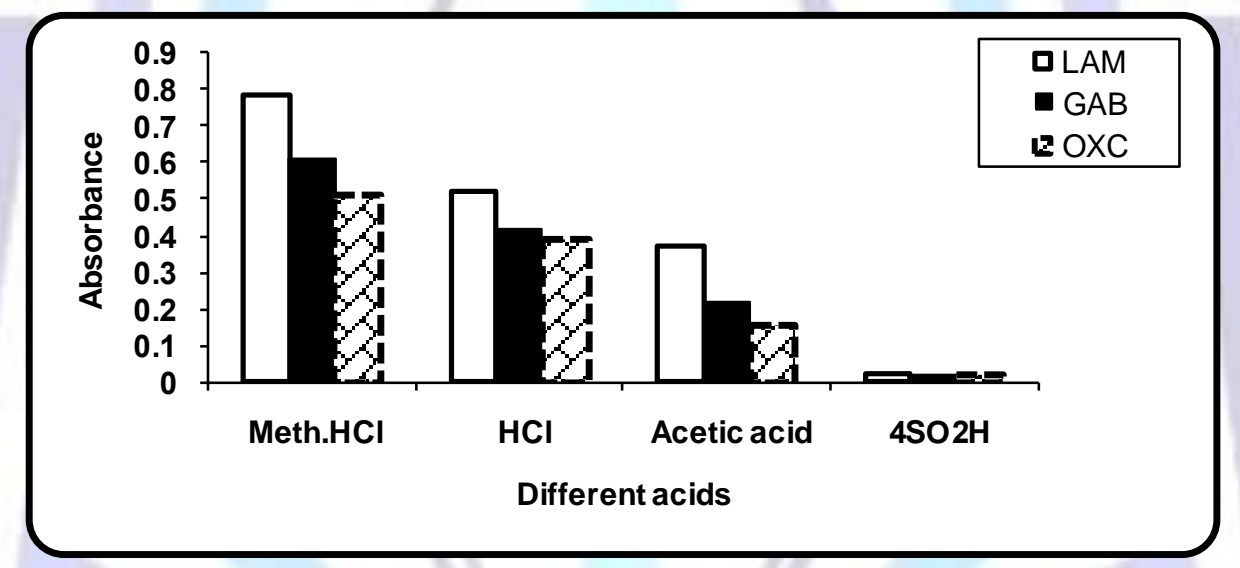

Figure 4 : Effect of different acids on absorbance of LAM $\left(10 \mu \mathrm{gml}^{-1}\right), \mathrm{GAB}\left(6 \mu \mathrm{gml}^{-1}\right)$, and OXC $\left(5 \mu \mathrm{gml} \mathrm{C}^{-1}\right)-\mathrm{Vanillin}$ $(5 \% \mathrm{w} / \mathrm{v})$ reaction products.

\subsubsection{Effect of reaction time}

The effect of time on the reaction was studied by carrying out the reaction for different periods of time $(0-30 \mathrm{~min})$. The reaction product's absorbance of $L A M, G A B$, and OXC with vanillin wasincreased by increas ing the time up to $20 \mathrm{~min}$. The color of the products formed was stable for about 2 hours at room temperature $\left(30^{\circ} \mathrm{C}\right)$ followed by a steady decrease in absorbance values as shown in Figure 5. 


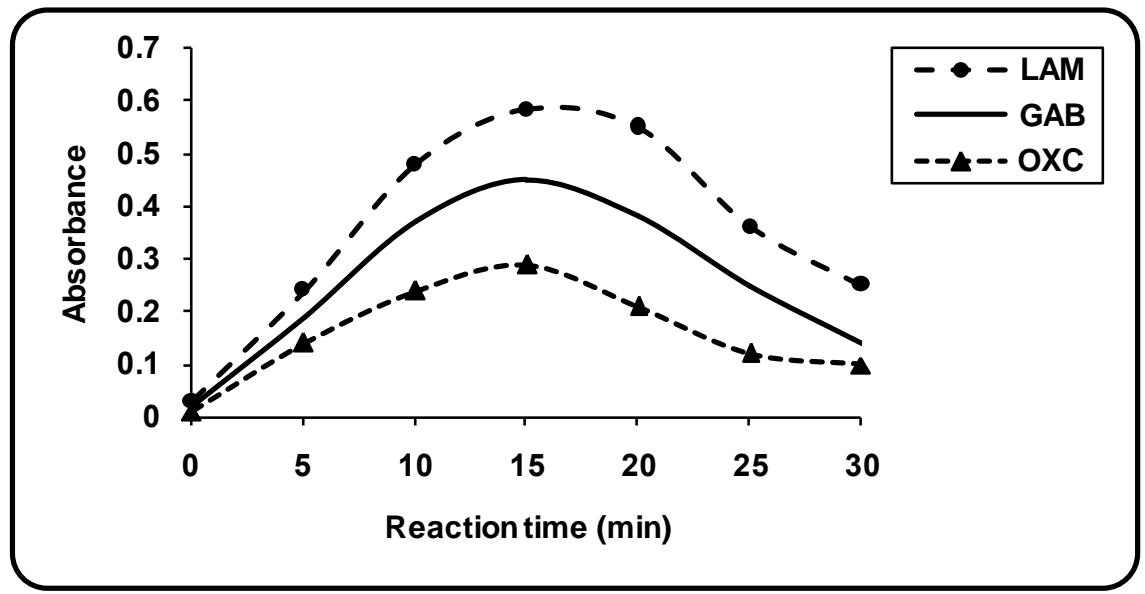

Figure 5: Effect of reaction time on absorbance of LAM $\left(6 \mu \mathrm{gml}^{-1}\right), \mathrm{GAB}\left(4 \mu \mathrm{gml}^{-1}\right)$, and OXC $\left(3 \mu \mathrm{gml}^{-1}\right)-\operatorname{Vanillin}(5 \%$ $\mathbf{w} / \mathrm{v})$ reaction products.

\subsubsection{Stability of the chromophore}

After dilution the reaction solutions, it was found that the absorbance of the chromophore (LAM-vanillin), (GABvanillin), and (OXC-vanillin) remained stable for at least 2 hours. Under the optimum experimental conditions the calibration curves were plotted representing the relationship between the absorbance at 405, 396 and $400 \mathrm{~nm}$ and the corresponding concentration of the three cited drugs (LAM, GAB, and OXC). Linear correlation coefficients were obtained within the concentration range (0.4-10), (0.1-10), and (0.5-11) $\mu \mathrm{g} / \mathrm{mLfor} L A M, G A B$, and OXC respectively.

\subsubsection{Stoichiometry of the reaction}

Under the optimum conditions, the stoichiometry of the reaction of LAM, GAB, and OXC with vanillin were determined adopting the Job's method of continuous variation [50]. The results revealed that LAM, GAB, and OXA reacted with vanillin in a ratio of 1:1 under the optimum condition attained Figure 6.

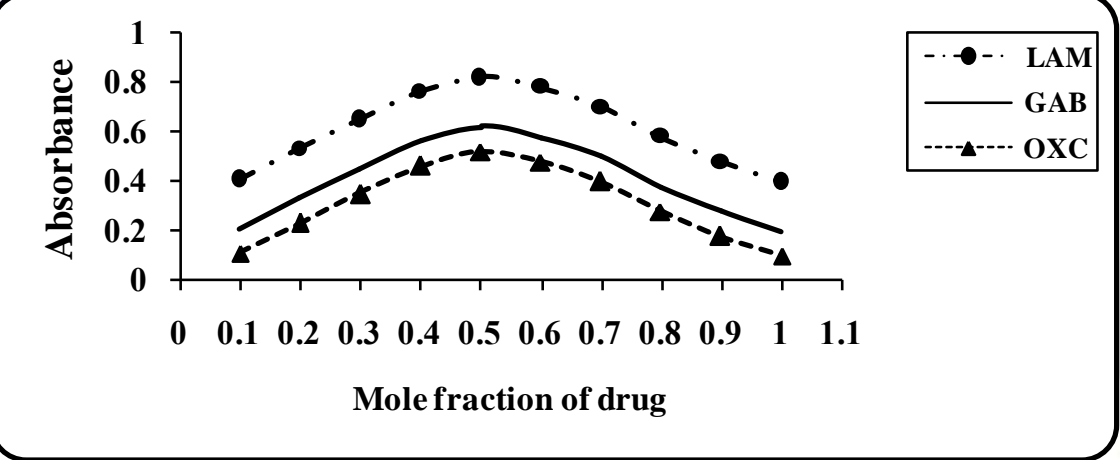

Figure 6 :Determination of Stoichiometry of the reaction of LAM, GAB, and OXC- vanillin (5\% w/v) by Continuous Variation method using $\left(2 \times 10^{-4} \mathrm{M}\right)$ solutions.

\subsubsection{Determination of the stability constant}

The stability constant $\left(\mathrm{K}_{f}\right)$ of the reaction products are calculated according to the follow equation:

$K_{f}=\left(A / A_{m}\right) /\left[1-A / A_{m}\right] n^{-1} C^{n} n^{n}[51]$

Where: $A=$ maximum absorbance of the continuous variation curve Figure $6, A_{m}=$ absorbance corresponding to intersection of two tangents of the continuous variation curve, $\mathrm{n}=$ number of molecules of the reagent in the reaction product, $\mathrm{C}=$ molar concentration of the drug and $\mathrm{K}_{\mathrm{f}}=$ formation constant of the complex.

The stability constant of the reaction products of LAM, GAB and OXC with vanillin were $4.2 \times 10^{4}, 1.8 \times 10^{4}$, and $2.4 \times 10^{3}$, respectively.

The Gibbs free energy change of the reaction $(\Delta G)$ [52] was also calculated adopting the following equation: $\Delta \mathrm{G}=-2.303 \mathrm{RT} \log \mathrm{K}_{f}$

Where: $\Delta G=$ Gibbs free energy change of the reaction (k.J. mol ${ }^{-1}$ )

$\mathrm{R}=$ Universal gas constant $(8.314$ joules $)$ 
$\mathrm{T}=$ Absolute temperature $\left(273+25^{\circ} \mathrm{C}\right)$

$\mathrm{K}_{f}=$ Formation constant of reaction

The free energy changes $(\Delta G)$ of the reaction LAM, GAB and OXC with vanillin was found to be $-6.3 \times 10^{4},-5.8 \times 10^{4}$ and $-4.6 \times 10^{4}$ k.J.mole ${ }^{-1}$ respectively, The higher $\mathrm{K}_{\mathrm{f}}$ and $\Delta \mathrm{G}$ values obtained indicate very stable reaction products.

\subsection{Method Validation}

\subsubsection{Analytical Parameters}

A linear relation was found to exist between absorbance and the concentration of LAM, GAB, and OXC in the range $(0.4-10),(0.1-10)$, and $(0.5-11) \mu \mathrm{g} / \mathrm{mLrespectively.} \mathrm{The} \mathrm{calibration} \mathrm{graph} \mathrm{is} \mathrm{described} \mathrm{by} \mathrm{the} \mathrm{equation:} Y=a+b C$ (where $\mathrm{Y}$ is the absorbance, $\mathrm{a}$ is the intercept, $\mathrm{b}$ is the slope and $\mathrm{C}$ is the concentration in $\mu \mathrm{g} / \mathrm{mL}$ ) obtained by the method of least squares. Correlation coefficient, intercept and slope for the calibration data are summarized in Table 1. Sensitivity parameters such as apparent molar absorptivity and Sandell's sensitivity values, the limits of detection and quantification calculated as per the current ICH Q2B guidelines [53] are compiled in Table 1 and are indicative of the excellent sensitivity of the method. The limits of detection (LOD) and quantification (LOQ) were calculated according to the same guidelines using the formulae: $L O D=3.3 \sigma / \mathrm{b}$ and $L O Q=10 \sigma / b$, where $b$ is slope of the calibration curve and $\sigma$ is standard deviation of $y$-intercept of regression equation Table 1.

Table 1:Sensitivity and regression parameters

\begin{tabular}{|c|c|c|c|}
\hline Parameters & Lamotrigine & Gabapentin & Oxcarbazepine \\
\hline$\Lambda \max$ & $405.0 \mathrm{~nm}$ & $396.0 \mathrm{~nm}$ & $400.0 \mathrm{~nm}$ \\
\hline Molar absorptivity $\left(\mathrm{L} \mathrm{mol}^{-1} \mathrm{~cm}^{-1}\right)$ & $2.52 \times 10^{4}$ & $1.74 \times 10^{3}$ & $2.54 \times 10^{4}$ \\
\hline Sandell sensitivity $\left(\mu \mathrm{cm}^{-2} / 0.001\right.$ abs unit $)$ & $10.23 \times 10^{-3}$ & $9.71 \times 10^{-3}$ & $9.82 \times 10^{-3}$ \\
\hline \multicolumn{4}{|l|}{ Regression equation $(\mathrm{Y}=\mathrm{bC}+\mathrm{a})$} \\
\hline Slope (b) & 0.0985 & 0.1017 & 0.1007 \\
\hline SD of slope & 0.000135 & 0.00083 & 0.00195 \\
\hline SE of slope & 0.000555 & 0.00034 & 0.00079 \\
\hline Confidence limit of slope & $0.09718-0.09989$ & $0.10083-0.10249$ & $0.09866-0.10275$ \\
\hline Intercept (a) & -0.001 & 0.0034 & 0.0043 \\
\hline SD of Intercept & 0.007153 & 0.004378 & 0.0125 \\
\hline S E of Intercept & 0.002921 & 0.001788 & 0.00508 \\
\hline Confidence limit of Intercept & $-0.00815-0.00615$ & $-0.00095-0.0078$ & $-0.00173-0.01738$ \\
\hline Correlation coefficient $(r)$ & 0.9998 & 0.9999 & 0.9997 \\
\hline SE of $(r)$ & 0.00533 & 0.00334 & 0.00779 \\
\hline \multicolumn{4}{|l|}{ Validation parameters } \\
\hline $\begin{array}{l}\text { Selectivity and Specificity } \\
\text { (t-test) }(2.228)\end{array}$ & 0.175 & 1.15 & 0.491 \\
\hline Accuracy $\left(\right.$ Mean $^{c} \pm$ RSD \%) & $99.845 \pm 0.867 \%$ & $99.0 \pm 0.957 \%$ & $99.916 \pm 0.862 \%$ \\
\hline Linearity $(\mu \mathrm{g} / \mathrm{ml})$ & $0.4-10.0 \mu \mathrm{g} / \mathrm{ml}$ & $0.1-10.0 \mu \mathrm{g} / \mathrm{ml}$ & $0.5-11.0 \mu \mathrm{g} / \mathrm{ml}$ \\
\hline Limit of detection [LOD] & $0.165 \mu \mathrm{g} / \mathrm{ml}$ & $0.049 \mu \mathrm{g} / \mathrm{ml}$ & $0.188 \mu \mathrm{g} / \mathrm{ml}$ \\
\hline Limit of quantitation [LOQ] & $0.500 \mu \mathrm{g} / \mathrm{ml}$ & $0.150 \mu \mathrm{g} / \mathrm{ml}$ & $0.570 \mu \mathrm{g} / \mathrm{ml}$ \\
\hline Robustness (mean\% recovery \pm S.D) & $100.11 \% \pm 0.545$ & $100.08 \% \pm 0.416$ & $100.4 \% \pm 0.583$ \\
\hline
\end{tabular}

$\mathrm{Y}=\mathrm{bC}+\mathrm{a}$ where $\mathrm{C}$ is the concentration of three drugs in $\mu \mathrm{g} / \mathrm{ml}$ and $\mathrm{Y}$ is absorbance unit. (Each value is a result of six separate determinations), c $95 \%$ confidence limit. 


\subsubsection{Accuracy}

The accuracy of the proposed method for drug substances and drug products was determined by investigating the percentage recovery at five levels each three times in the concentration range $3.0-11.0 \mu \mathrm{g} / \mathrm{ml}$ as shown in Table 2. The percentage relative standard deviation (\% RSD) revealed high accuracy.

Table 2: Accuracy of the proposed method in drug substances and drug products

\begin{tabular}{|c|c|c|c|c|c|c|}
\hline \multirow{5}{*}{$\begin{array}{l}\text { Conc. } \\
\text { taken } \\
\mu \mathrm{g} / \mathrm{ml}\end{array}$} & \multicolumn{2}{|c|}{ Lamotrigine } & \multicolumn{2}{|c|}{ Gabapentin } & \multicolumn{2}{|c|}{ Oxcarbazepine } \\
\hline & \multirow[t]{3}{*}{ Drug subs. } & Drug product & \multirow[t]{3}{*}{ Drug subs. } & Drug product & \multirow[t]{3}{*}{ Drug subs. } & Drug product \\
\hline & & Laroge & & Gaptin & & Trileptal \\
\hline & & $100 \mathrm{mg} / \mathrm{tab}$ & & $100 \mathrm{mg} / \mathrm{tab}$. & & $150 \mathrm{mg} / \mathrm{tab}$. \\
\hline & \multicolumn{2}{|c|}{ Recovery $(\%)^{a}$} & \multicolumn{2}{|c|}{ Recovery $(\%)^{a}$} & \multicolumn{2}{|c|}{ Recovery $(\%)^{a}$} \\
\hline 3 & 99.23 & 99.51 & 98.33 & 99.67 & 99.52 & 99.11 \\
\hline 5 & 99.56 & 98.72 & 98.91 & 98.31 & 98.92 & 98.64 \\
\hline 7 & 98.21 & 99.66 & 98.73 & 97.99 & 100.02 & 99.09 \\
\hline 9 & 97.75 & 98.90 & 99.64 & 99.12 & 101.0 & 99.82 \\
\hline 11 & 100.0 & 98.81 & 101.0 & 99.25 & 99.76 & 98.76 \\
\hline Mean \pm & 98.95 & 99.12 & 99.32 & 98.87 & $99.84 \pm$ & 99.08 \\
\hline RSD\% & \pm 0.951 & \pm 0.436 & \pm 1.05 & \pm 0.703 & 0.765 & \pm 0.463 \\
\hline
\end{tabular}

${ }^{a}$ Average from four different experiments. For drug product, recovery is given as a percentage of the amount claimed table.

\subsubsection{Precision}

The intraday precision was evaluated by assaying freshly prepared solutions in triplicate in the concentration range $2.0-16.0 \mu \mathrm{g} / \mathrm{ml}$ as shown in Table 3. The percentage relative standard deviations (\%RSD) were calculated. While interday precision was calculated by assaying freshly prepared solutions in triplicate for three days. The percentage relative standard deviations (\%RSD) were calculated as shown in Table 3.

Table 3: Evaluation of intra-day and inter-day of precision

\begin{tabular}{|c|c|c|c|c|c|c|c|c|c|c|c|c|}
\hline \multirow{3}{*}{$\begin{array}{l}\text { Drug } \\
\text { taken } \\
\mu \mathrm{g} \\
/ \mathrm{ml}\end{array}$} & \multicolumn{4}{|c|}{ Lamotrigine } & \multicolumn{4}{|c|}{ Gabapentin } & \multicolumn{4}{|c|}{ Oxcarbazepine } \\
\hline & \multicolumn{2}{|c|}{$\begin{array}{l}\text { Intra-day } \\
\text { accuracy and } \\
\text { precision }\end{array}$} & \multicolumn{2}{|c|}{$\begin{array}{l}\text { Inter-day } \\
\text { accuracy and } \\
\text { precision }\end{array}$} & \multicolumn{2}{|c|}{$\begin{array}{l}\text { Intra-day accuracy } \\
\text { and precision }\end{array}$} & \multicolumn{2}{|c|}{$\begin{array}{l}\text { Inter-day accuracy } \\
\text { and precision }\end{array}$} & \multicolumn{2}{|c|}{$\begin{array}{l}\text { Intra-day } \\
\text { accuracy and } \\
\text { precision }\end{array}$} & \multicolumn{2}{|c|}{$\begin{array}{l}\text { Inter-day } \\
\text { accuracy and } \\
\text { precision }\end{array}$} \\
\hline & $\begin{array}{l}\text { Lam. } \\
\text { found }\end{array}$ & RSD\% & $\begin{array}{l}\text { Lam. } \\
\text { found }\end{array}$ & RSD\% & $\begin{array}{l}\text { Gab. } \\
\text { found }\end{array}$ & RSD\% & $\begin{array}{l}\text { Gab. } \\
\text { found }\end{array}$ & RSD\% & $\begin{array}{l}\text { Oxc. } \\
\text { found }\end{array}$ & RSD\% & $\begin{array}{l}\text { Oxc. } \\
\text { found }\end{array}$ & RSD\% \\
\hline 4 & 4.02 & 0.123 & 3.90 & 0.505 & 4.00 & 0.214 & 3.89 & 0.641 & 4.06 & 0.136 & 3.95 & 0.321 \\
\hline 6 & 6.10 & 0.265 & 6.01 & 0.541 & 6.05 & 0.341 & 5.97 & 0.521 & 6.03 & 0.710 & 5.94 & 0.221 \\
\hline 8 & 8.01 & 0.348 & 8.04 & 0.364 & 7.90 & 0.721 & 7.99 & 0.543 & 8.01 & 0.213 & 8.00 & 0.334 \\
\hline
\end{tabular}

RSD\%: relative standard deviation.

\subsubsection{Robustne ss and ruggedne ss}

Method robustness was tested by making small incremental changes in volume of vanillin rang of Temp. To check the ruggedness, analysis was performed by three different analysts and on three different spectrophotometers by the same analyst. The robustness and the ruggedness were checked at three different drugs levels. The intermediate precision, expressed as percent RSD, which is a measure of robustness and ruggedness was within the acceptable limits as shown in the Table 4. 
Table 4: Robustness and ruggedness expressed as intermediate precision (\% RSD)

\begin{tabular}{|c|c|c|c|c|}
\hline \multirow[b]{3}{*}{ Drugs } & \multicolumn{2}{|c|}{ Method Robustness } & \multicolumn{2}{|c|}{ Method Ruggedness } \\
\hline & \multicolumn{4}{|c|}{ Parameters altered } \\
\hline & $\begin{array}{l}\text { Vanillina (5\%) } \\
\text { ml, } \\
\text { RSD \% }(n=3)\end{array}$ & $\begin{array}{l}\text { Change in } \\
\text { Tempb.(30oC) } \\
\text { RSD \% }(n=3)\end{array}$ & $\begin{array}{l}\text { Inter-analysts' } \\
\text { RSD \% }(n=3)\end{array}$ & $\begin{array}{l}\text { Inter-ins truments' } \\
\text { RSD \% }(n=3)\end{array}$ \\
\hline Lamotrigine & $0.755 \%$ & $0.252 \%$ & $0.261 \%$ & $0.448 \%$ \\
\hline Gabapentin & $0.843 \%$ & $0.836 \%$ & $0.684 \%$ & $0.297 \%$ \\
\hline Oxcarbazepine & $0.794 \%$ & $0.504 \%$ & $0.107 \%$ & 0.905 \\
\hline
\end{tabular}

$\mathrm{a}=$ vanillin volumes were used $2.1,2.3,2.5 \mathrm{ml}$.

$\mathrm{b}=$ change in Temp. $30.2,30.4,30.6{ }^{\circ} \mathrm{C}$.

\subsubsection{Method Validation for Drug Products}

It is evident from the above-mentioned results that the proposed method gave satisfactory results with LAM, $G A B$, and $O X C$ in its drug substances. Thus its drug products were subjected to the analys is of their $L A M, G A B$, and $O X C$ contents by the proposed and the potentiometric method for LAM (4), official HPLC method for GAB (4) and official HPLC method for OXC (28). The label claim percentages were $99.12 \pm 0.436 \%, 99.32 \pm 1.05 \%$, and $99.08 \pm 0.463 \%$ for LAM, GAB, and OXC, respectively Table 5. These results were compared with those obtained from the official methods by statistical analys is with respect to the accuracy (by $t$ - test) and precision (by $F$ - test). No significant differences were found between the calculated and theoretical values of $t$-test and $F$-test at $95 \%$ confidence level proving similar accuracy and precision in the determination of LAM, GAB and OXC by UV method.

Table 5: Results of analysis of tablets by the proposed method

\begin{tabular}{|c|c|c|c|c|c|c|}
\hline & \multicolumn{2}{|c|}{$\begin{array}{l}\text { Lamotrigine } \\
\text { Larogen } \\
100 \text { mg/tab }\end{array}$} & \multicolumn{2}{|c|}{$\begin{array}{c}\text { Gabapentin } \\
\text { Gaptin } \\
100 \mathrm{mg} / \mathrm{tab} .\end{array}$} & \multicolumn{2}{|c|}{$\begin{array}{c}\text { Oxcarbazepine } \\
\text { Trileptal } \\
150 \mathrm{mg} / \mathrm{tab} \text {. }\end{array}$} \\
\hline & $\begin{array}{c}\text { proposed } \\
\text { method }\end{array}$ & $\begin{array}{c}\text { HPLC } \\
\text { method [3] }\end{array}$ & proposed method & $\begin{array}{c}\text { HPLC } \\
\text { method [3] }\end{array}$ & $\begin{array}{c}\text { Proposed } \\
\text { method }\end{array}$ & $\begin{array}{c}\text { HPLC } \\
\text { method [3] }\end{array}$ \\
\hline $\begin{array}{l}\text { Mean }^{\star} \\
\pm R S D \%\end{array}$ & $\begin{array}{l}99.57 \pm \\
0.483 \%\end{array}$ & $\begin{array}{l}99.53 \pm \\
0.49 \%\end{array}$ & $\begin{array}{l}99.77 \pm \\
0.216 \%\end{array}$ & $\begin{array}{c}99.65 \pm \\
0.182 \%\end{array}$ & $\begin{array}{l}99.61 \pm \\
0.272 \%\end{array}$ & $\begin{array}{l}99.54 \pm \\
0.253 \%\end{array}$ \\
\hline Variance & 0.231 & 0.238 & 0.046 & 0.033 & 0.073 & 0.064 \\
\hline$S E$ & 0.196 & 0.199 & 0.086 & 0.074 & 0.111 & 0.103 \\
\hline $\begin{array}{l}\text { t-test } \\
(2.228)^{a}\end{array}$ & 0.144 & & 0.902 & & 0.461 & \\
\hline $\begin{array}{l}\text { F-test } \\
(5.1)^{a}\end{array}$ & 1.030 & & 1.39 & & 1.14 & \\
\hline
\end{tabular}

a) Theoretical values

\section{CONCLUSION}

A simple, sensitive and rapid method for the determination of $L A M, G A B$ and $O X C$ in its drug products are described, involving the use of vanillin as a chromogenic agent. The method is rapid and less tedious than many reported spectrophotometric methods. The present method can be applied at ambient temperature; color development is instantaneous and does not require strict $\mathrm{pH}$ control or tedious liquid-liquid extraction step. The method employs inexpensive and easily available chemicals and instrument. As most relevant features of the method, hig h sensitivity and a wide linear dynamic range compared to many existing methods can be emphasized. The color formed is highly stable leading to very precise results. These advantages make the method a valuable altemative to many existing methods for the determination of LAM, GAB and OXC in drug substances and can be applied in biological fluids. 


\section{REFERENCES}

[1] Gilman A.G., Hardman J.G., Limbered L.E.2001. Goodman and Gilman's the Phamacological Basis of Therapeutics. 10th ed. McGraw Hill, New York, U.S.A. pp. 539

[2] Sean C., Sweet man.2007. Martindale: The Complete Drug Reference $34^{\text {th }}$ ed. Pharmaceutical Press, London. pp. 363 LAM, p.442 OXC

[3] United States Phamacopeia $37^{\text {th }}$ ed., The United States Phamacopeial convention Inc., Twin brook Parkway, Rockville.2014; pp. 3486,3488,3106,3108, 4116, 4119.

[4]J. Emami,N.Ghassami,F. Ahmadi,"Development and validation of a new HPLC method for detemination of lamotrigine and related compounds in tablet fomulations ",J. Pham Biomed Anal, 2006, 40(4): 999-1005.

[5] C .Greiner,E. Halen," development and validation of indirect spectrophotometric methods for lamotrigine in pure and the tablet dosage forms", J. Chromatogram B, 2007, 854(1-2): 338-344.

[6]N. EL-Enany,D. El-Sherbiny,A.Abdulla,F.Belal," Hydrophilic interaction liquid chromatography: a worthy technique for the determination of lamotrigine in tablets and human plasma", J. Liquid Chromatography \& Related Technologies, 2012, 35:819-833.

[7]E. Greiner-Solano,S. Giannoutsos,D. R. Lower, Virgil M A, M. D.Krasowski," Drug monitoring: simultaneous analysis of lamotrigine, oxcarbazepine, 10-hydroxycarbazepine, and zonisamide by HPLC-UV and a rapid GC method using a nitrogen-phosphorus detector for levetiracetam ",J. Chromatogram Sci., 2007, 45: 616-622.

[8]V. puce,F. Bagatelle,C.Boccioni,M. A.Reggie,"Analysis of lamotrigine and its metabolites in human plasma and urine by micelles electro kinetic capillary chromatography", Electrophoresis, 2005, 26: 935-942.

[9] O. Domínguez-Renedo, M.IncarnationburgooCalve, M. Arcos-Martinez,"Determination of Lamotrigine in Pharmaceutical Preparations by Adsorptive Stripping Voltammetry Using Screen Printed Electrodes",Sensors (Basel). 2008; 8(7): 4201-4212.

[10]M. E. Burgoo Calve,O. C. Rene do ,M. J.Arcos Martinez,"Determination of lamotrigine by adsorptive stripping voltammetry using silver nanoparticle-modified carbon screen-printed electrodes". Anal Chim Acta, 2005, 549: 7480.

[11]A. M.Saracens,F. Bagatelle,M. Conti,M.Amore,M. A. Reggie," Extractive Visible Spectrophotometric Detemination of Lamotrigine in Pure and Pharmaceutical Formulations", J. Sep Sci., 2007, 30: 2249-2255.

[12]L.Zulia,A.Aldan,N.Ibanez,C.Vitter, "Extractive Visible Spectrophotometric Determination of Lamotrigine in Pure and Phamaceutical Formulations", Chem Sci Trans., 2013, 2(3):1016-1020

[13]N. Sinai, K.Sinai, "Quantitative determination of lamotrigi1ne in bulk and dosage form by UV Spectrophotometry", Journal of Applied Phamaceutical Science 01 (03);2011:113-116

[14] N. Rajendraprasad,K. Basavaiah,K.B. VI nay, "Sensitive spectrophotometric detemination of lamotrigine in bulk drug and phamaceutical formulations using bromocresol green", Éclat. Qualm. vol.35 no.12010 São Paulo.

[15]N.Palisade, R. Khakinahad, Jabber,"Spectrophotometric detemination of lamotrigine in pharmaceutical preparations and urine by charge-transfer complexion",Phamazie. 2008;63(11):791-5

[16]N. malleswara,S.Pularuddy,S.Verdean,C.Rambus," Extractive Visible Spectrophotometric Determination of Lamotrigine in Pure and Phamaceutical Formulations", Chem Sci Trans., 2013, 2(3): 1016-1020

[17]M.Faddily, H. H .Kiser," Spectrophotometric determination of lamotrigine in phamaceutical preparations and urine samples using bromothymol blue and bromophenol blue", The Malaysian Journal of Analytical Sciences, Vol. 17 No $2(2013): 310-325$.

[18]D. Weintraub,R. Buchsbaum,S.R.Resort,L.J. Hirsch,"Psychiatric and behavioral side effects of the newerantiepileptic drugs in adults with epilepsy", Epilepsy and Behavior. 10(1): 105-110(2007).

[19] D.R.Ifa,M.Falco,M.E.Morales, F.A.Bizarre,M.O.Morales, G.de Nicki," Gabapentin quantification in human plasma by high performance liquid chromatography coupled to electrospray tandem mass spectrometry: Application to bioequivalence study",J Mass Spectrum 2001; 36(2): 188-94.

[20]M.M.Kushner,J. Crossett,P.I. Brown,F.M.Uris," Analys is of Gabapentin in serum and plasma by solid-phase extraction and gas chromatography-mass spectrometry for therapeutic drug monitoring", J Anal Toxicol 1999;23(1):1-6

[21]L.L. Garcia,Z.K.Shahabad, K.Oleos," Determination of Gabapentin in serum by capillary electrophoresis", JChromatograph. Biomed Appl. 1995; 669(1):157-62.

[22]F.Jalal, E .Akan,G.Bah rami,"Preparation of a Gabapentin Potentiometric sensor and its application to pharmaceutical analysis", Sen.Acute B Chem 2007; 127 (1): 304-309. 
[23]E.M. Hassan,F.Bella,O.A. Al-Deep,N.Y. Khalil," Spectrofluorimetric determination of vigabatrin and Gabapentin in dosage forms and spiked plasma samples through derivatization with 4-chloro-7- nitrobenzo-2-oxa-1, 3-diazole", J. AOAC 2001; 84(4):1017-24.

[24] H.E. Abdellatef,H.M. Khalil,"Colorimetricdetermination of Gabapentin in pharmaceutical formulation", J. Pharm Biomed Anal 2003; 5, 31(1):209-14

[25]P. Rajesh, P. Japan, S.Hardee, Bhagirathi," Extractive Spectrophotometric Methods for the Determination of Gabapentin in Pharmaceutical Dosage Forms", International Joumal of Pharmaceutical Sciences and Drug Research 2011; 3(3): 197-201

[26] S. Ambalal, J. Natavarlal,"Visible Spectrophotometric Methods for Determination of Gabapentin in Pharmaceutical Tablet and Capsule Dosage Forms ",Asian Joumal of Phamacy and Life Science ISSN 2011, Vol. 1 (3), 2231 - 4423

[27] A.Sameer, M.Abdurrahman , K. Basavaiah,"Sensitive and Selective Spectrophotometric Determination of Gabapentin in Capsules Using Two Nitro phenols as Chromogenic Agents", International Journal of Analytical Chemistry Volume 2011 (2011), Article ID 619310, 9 pages.

[28] Budavari S (ed.). The Merck Index 13th edition. Merck \& Co., Inc., New Jersey. 6998.

[29] Bang L, Goa K. (2003) Oxcarbazepine: a review of its use in children with epilepsy. Pediatric Drugs; 5(8): 557-73.

[30] Wellington K, Goa KL. (2001) Oxcarbazepine: An update of its efficacy in the management of epilepsy. CNS Drugs; 15(2): 137-63.

[31]A.Y. El-Saied,N.A. El-Salem," Recent development of derivative spectrophotometry and their analytical applications ", Analytical Science. 2005;21:595.

[32]S.Abuja, H.Rasmussen," HPLC Method Development for Pharmaceuticals ", London: Elsevier, 2007, Academic Press.

[33] D.B.Pithier,A.S.Judah, M.S.Shangri," A validated stability indicating LC method for oxcarbazepine" J. Pharmaceutical and Biomedical Analysis.2007; 43:1825-30.

[34]H.Leveret, P. Odium,H. Robert," LC detemination of oxcarbazepine and its active metabolite in human serum ", J. Pham. Biomed. Anal. 2002; 28: 517-25.

[35]N.Wad,"Simultaneous detemination of eleven antiepileptic compounds in serum by high performance liquid chromatography", J. Chromatograph. 1984; 305:127-33.

[36]M.C.Rouen,M.Decherd,V. Le Clenched,J.B. Lecaillon, J. God billon, "Automated microanalysis of oxcarbazepine and its monohydroxy and transdiolmetabolites in plasma by liquid chromatography", J. Chromatogr.B. 1994;658:167-72.

[37] K.M.Matter,P.J. Nicholls,M.I. Al-Hassan, A.Tackle," Rapid micro method for simultaneous measurement of oxcarbazepine and its active metabolite in plasma by high-performance liquid chromatography", J. Cline. Pharm.1995;20:229-34.

[38] G.E.Von Unruh, W.D.Par," Gas chromatographic assay for oxcarbazepine and its main metabolites in plasma", J. Chromatograph, Biomedical Applications.1985; 345:67-76.

[39] I.Niota's,V. Kimiskidis, M .Savakis,D.Kais,C .Gabriela,F.I.Kinase,D. Divanoglou," Development and validation of a high performance liquid chromatographic method for the determination of oxcarbazepine and its main metabolites in human plasma and cerebrospinal fluid and its application to phamacokinetic study", J. Pharmaceutical and Biomedical Analysis. 2007; 43: 763-8.

[40]M.Incarnation,O.D.Rene do, M.Julia," Determination of oxcarbazepine by square wave adsorptive stripping voltammetry in phamaceutical preparations", J. Pharmaceutical and Biomedical Analysis. 2007; 43:1156-60.

[41]N. Nikita,K.S.Rajesh,R.Paragon,R.Jots,A.Salish,S.Chary, "Development and Validation of Zero and First Order Derivative Spectrophotometric Methods For Determination of Oxcarbazepine In Phamaceutical Dosage Forms ", Pham a gene, 2013, 1, 1.

[42] M.Sothic,G. Nagendrappa, "Spectrophotometric detemination of oxcarbazepine in phamaceutical fomulations", International Joumal of Pharmacy and Pharmaceutical Sciences 2010, vol. 2, Supple 3.

[43]N. Rajendraprasad, K.Basavaiah, K.B.Vine, "Volumetric and spectrophotometric determination of oxcarbazepine in tablets",Acta Chim Slov. 2011; 58(3):621-8.

[44]A. Mohamed,M. Saied,H. Osama,F. Hassan, "A Novel Spectrophotometric Method for Determination of Five 1,4Dihydropyridine Drugs in Their Tablets and Capsules Using Vanillin Reagent", American Journal of Analytical Chemistry, 2013, 4, 148-157

[45]O.Zenith Devi, K .Basavaiah,K.B.Vine,H.D.Revanasiddappa, "Sensitive spectrophotometric determination of metoclopramide hydrochloride in dosage forms and spiked human urine using vanillin", Arabian Journal of Chem istry (2011).

[46]K. Medikondu,A. Koteswarao, M.Janardhan," New Spectrophotometric Methods for Quantitative Determination of 7 ADCA in Pharmaceutical Fomulations", IJPSR, 2010, Vol.1 (8): 312-319. 
[47]O.G.EnochFlorence, "Spectrophotometric detemination of isoniazid in pure and pharmaceutical formulations using vanillin", International Journal of Pharmacy and Phamaceutical Sciences 2010 Vol . 2, Supple 1.

[48] K. Siddappa, M. Mallikarjun,P. T. Reddy,M.Tambo, "Spectrophotometric detemination of metronidazole through Schiff's base system using vanillin and PDAB reagents in phamaceutical preparations", Éclat. Qualm. 2008 vol.33 no.4

[49]A. Nabil,B. Alhemiarya,H. Mohammed, A.Salah, "Spectrophotometric Determination of Tinidazole Using Promethazine and Ethyl Vanillin Reagents in Phamaceutical Preparations", DerPham Chemica, 2012, 4(6):2152-2160.

[50]Braun R. D., (1987) "Introduction to Instrumental Analysis", McGraw-Hall, New York.

[51] InchedJ., (1976) "Analytical Application of Complex Equilibra" John Wiley\& Sons Inc., Budapest.

[52]Martin A N, Swarbrick J, Cammarata A, " Physical Pharmacy", 3rd ed., Lea and Fibiger, Philadelphia, (1983), pp. 108,359 ,

[53]Guidance for industry bio analytical method validation US Department of Health and Human Services, Food and Drug Administration, Center for Drug Evaluation and Research, Rockville, MD, 2001, http://www.fda.gov/eder/ guidance/4252fnl.pdf (accessed September),( 2004). 